\title{
A Comparison between The Effect of Sub-lethal Doses of Atrazine and DDT on Brain and Plasma Acetylcholinesterase of the African Catfish (Clarias gariepinus)
}

\author{
H. ASSEM ${ }^{1}$ and I. Elsaeidy \\ National Institute of Oceanography and Fisheries, \\ Alexandria, Egypt
}

\begin{abstract}
The effect of in vivo exposure to two sublethal concentrations of atrazine and one concentration of DDT on acetylcholinesterase in brain and plasma of the fresh water fish Clarias gariepinus was measured. Blood and brain were taken after various periods of exposure (3-168 hr for atrazine and 3-24 hr for DDT). Controls were treated parallel. A real inhibition of brain AChE specific activity was detected by exposure $\mathrm{hr} 6$ at the lower atrazine concentration and by exposure $\mathrm{hr} 9$ at the higher concentration. The remainder of changes were considered false due to changes in brain water content and/or protein content. The effect of DDT was restricted to a real activation only by exposure $\mathrm{hr} 6$. Plasma AChE specific activity increased throughout the whole experimental time during exposure to the lower concentration of atrazine, while reduction was recorded in the beginning and toward the end of experiment at the higher concentration. Plasma AChE activity during DDT exposure ranged from initial decrease followed by increase, then inhibition and finally activation which could give an indication that DDT is more harmful than atrazine at its higher concentration $(500 \mu \mathrm{g} / 1)$. Although the changes are clear in the enzyme activity of the brain, plasma $\mathrm{AChE}$ seems to be more useful as a monitor of exposure to anticholinesterase chemicals.
\end{abstract}

\section{Introduction}

The esterase inhibiting insecticides (organophosphate and carbamates) are now produced and enter the environment in greater quantities than the chlorinated hyd-

\footnotetext{
${ }^{1}$ To whom requests for reprints be addressed at: National Institute of Oceanography, Al Anfoshy, Alexandria, Egypt.
} 
to which $250 \mathrm{ml}$ of sodium bicarbonate $(60 \mathrm{mg} / \mathrm{ml})$ were added. The DTNB solution is stable for 2 to 3 days if stored at $4^{\circ} \mathrm{C}$.

All assays of AChE activity were performed in duplicate and employed $2.8 \mathrm{ml}$ homogenate solution to which $100 \mu l$ DTNB and $50 \mu \mathrm{l}$ ASCh solutions were added. ASCh concentration in the cuvettes was $10 \mathrm{mM}$ and corresponded to the substrate level for maximum activity. An additional preparation without ASCh served as the blank. The change in absorbance initiated by the addition of ASCh was monitored from 1 to 5 min on spectrophotometer equipped with chart recorder at wavelength of $512 \mathrm{~nm}$. Total AChE activities were expressed as nmol ASCh hydrolysed per minute calculated from the change in absorbance per min, given an extension coefficient of $1.36 \times 10^{4} \mathrm{M}^{-1} \mathrm{~cm}^{-1}$. Brain tissue enzyme specific activity is given in terms of unit/ mg protein.

\section{Results}

\section{Brain AChE Activities}

Specific activity

The alteration in the enzyme specific activity after treatment with atrazine are given in Fig. 1.

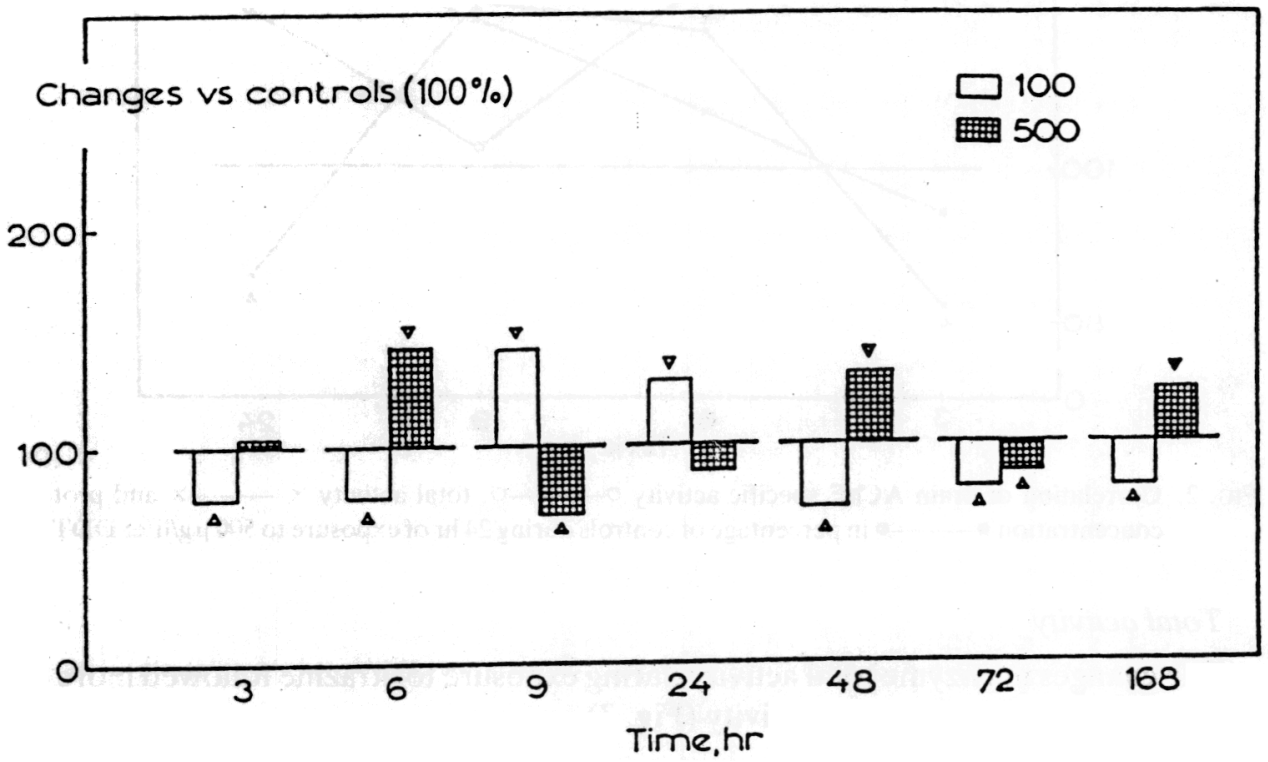

FIC Changes of brain AChE specific activity level in percentage of controls during $168 \mathrm{hr}$ of exposure to $100,500 \mu \mathrm{g} /$ liter atrazine.

The AChE activity was decreased by exposure $\mathrm{hr} 3$ and 6 at the lower atrazine concentration $(100 \mu \mathrm{g} /$ liter $)$. This initial inhibition was followed by a rapid activation to 


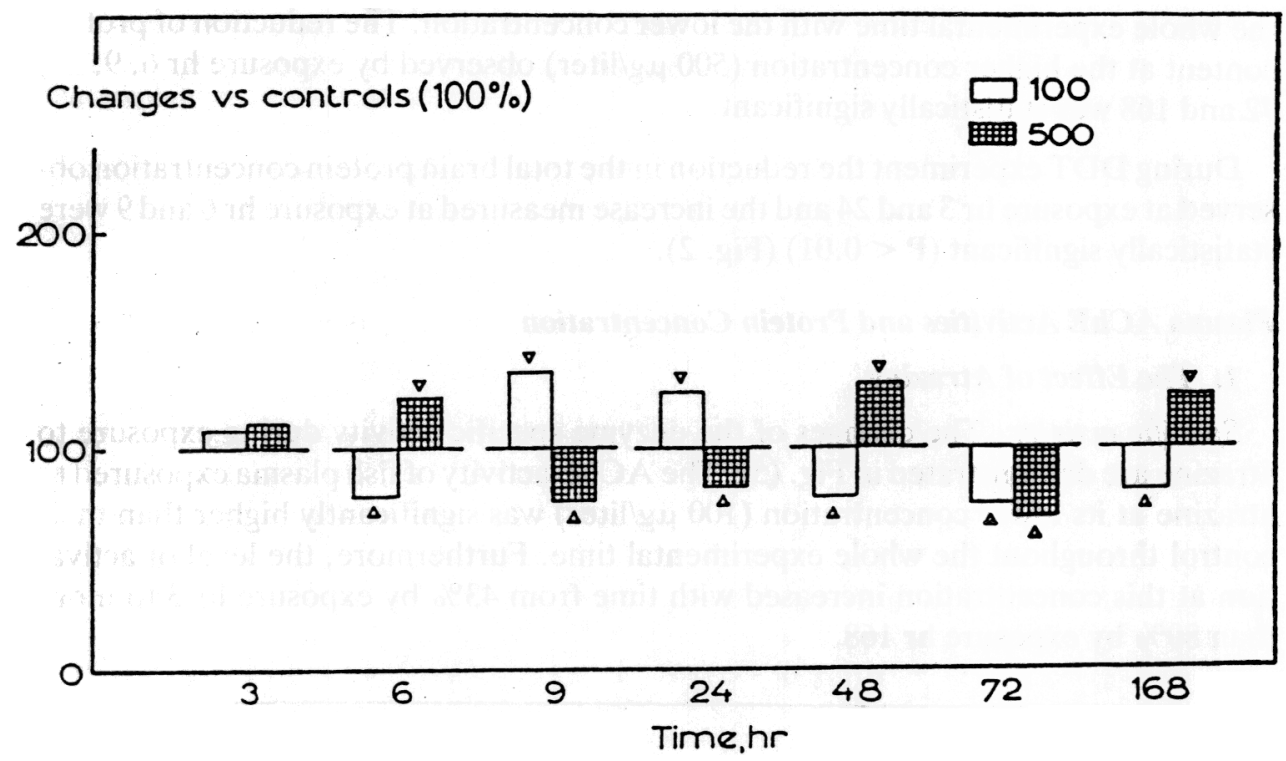

FIG. 3. Changes of brain AChE total activity in percentage of controls during $168 \mathrm{hr}$ of exposure to 100 , $500 \mu \mathrm{g} /$ /iter atrazine.

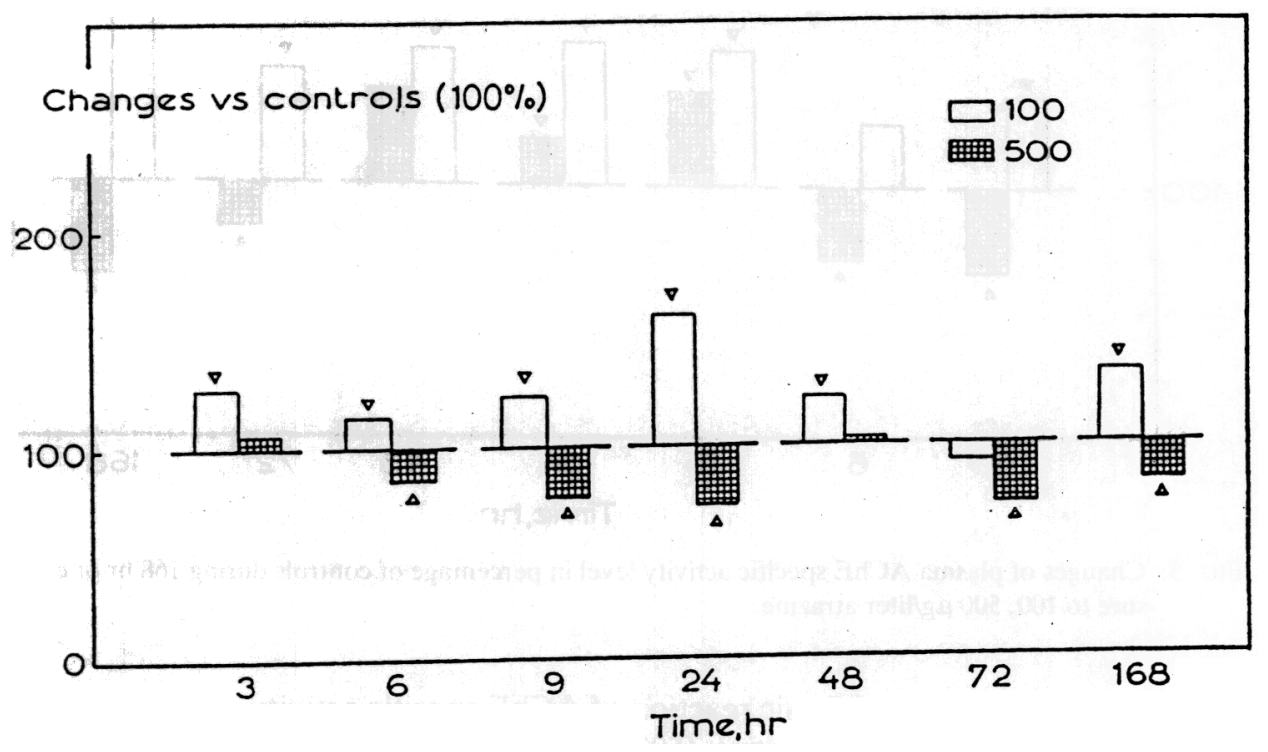

FIG. 4. Changes of brain protein concentration in percentage of controls during $168 \mathrm{hr}$ of exposure to 100 , $500 \mu \mathrm{g} /$ liter atrazine. 
Total activity. Plasma AChE total activity was rapidly increased $3 \mathrm{hr}$ after exposure to the lower atrazine concentration $(100 \mu \mathrm{g} / \mathrm{liter})$. The reduction in the enzyme activity recorded later reached a maximum at exposure hr 24 (ca. 80\%). Afterwards enzyme activity has been increased from the 48th throughout the rest of the experimental time.

Atrazine at the higher concentration produced a rapid and highly significant inhibition of the enzyme total activity during the first $9 \mathrm{hr}$ of exposure. The recovery of control level was observed during the following 24 and 48 test time. The subsequent second inhibition at exposure $\mathrm{hr} 72$ and 168 was statistically significant $(P<0.001)$ (Fig. 6).

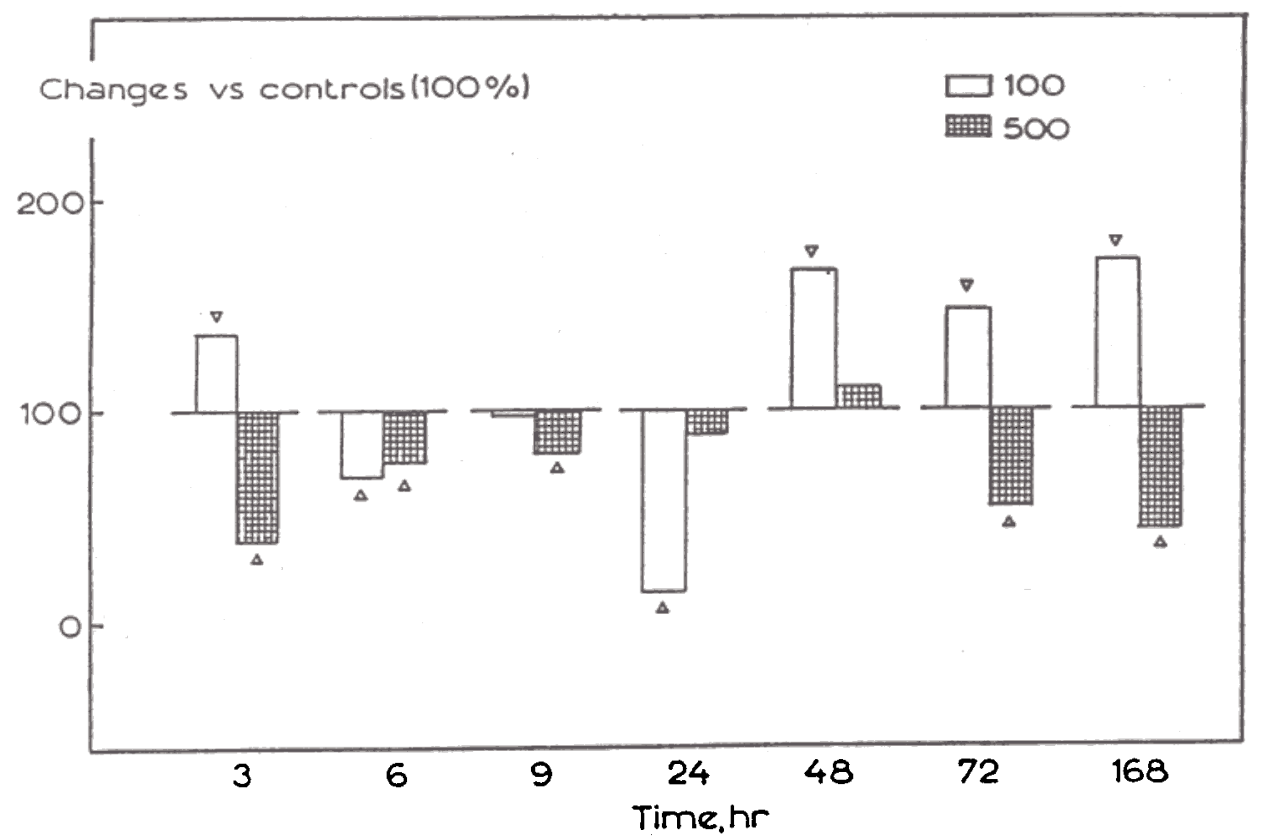

FIG. 6. Changes of plasma AChE total activity level in percentage of controls during $168 \mathrm{hr}$ of exposure to $100,500 \mu \mathrm{g} /$ liter atrazine.

Protein concentration. Fig (7) summarizes the changes of total plasma protein concentration. A significant decrease of plasma protein (7-15\%) was measured during the first $24 \mathrm{hr}$ in fish exposed to the lower atrazine concentration $(100 \mu \mathrm{g} / \mathrm{liter})$. The increase in plasma protein at exposure $\mathrm{hr} 48,72$ and 168 was not statistically different from that of the corresponding controls.

Exposure to atrazine at the higher concentration $(500 \mu \mathrm{g} / \mathrm{liter})$ resulted in a short $(6 \mathrm{hr})$ and rapid increase of the plasma protein which was followed by a decrease to a maximum of $50 \%$ at exposure $\mathrm{hr} 48$, this decrease tends downwards to a level which still significantly $(\mathrm{P}<0.05)$ lower than the controls $(9.0 \%)$. 


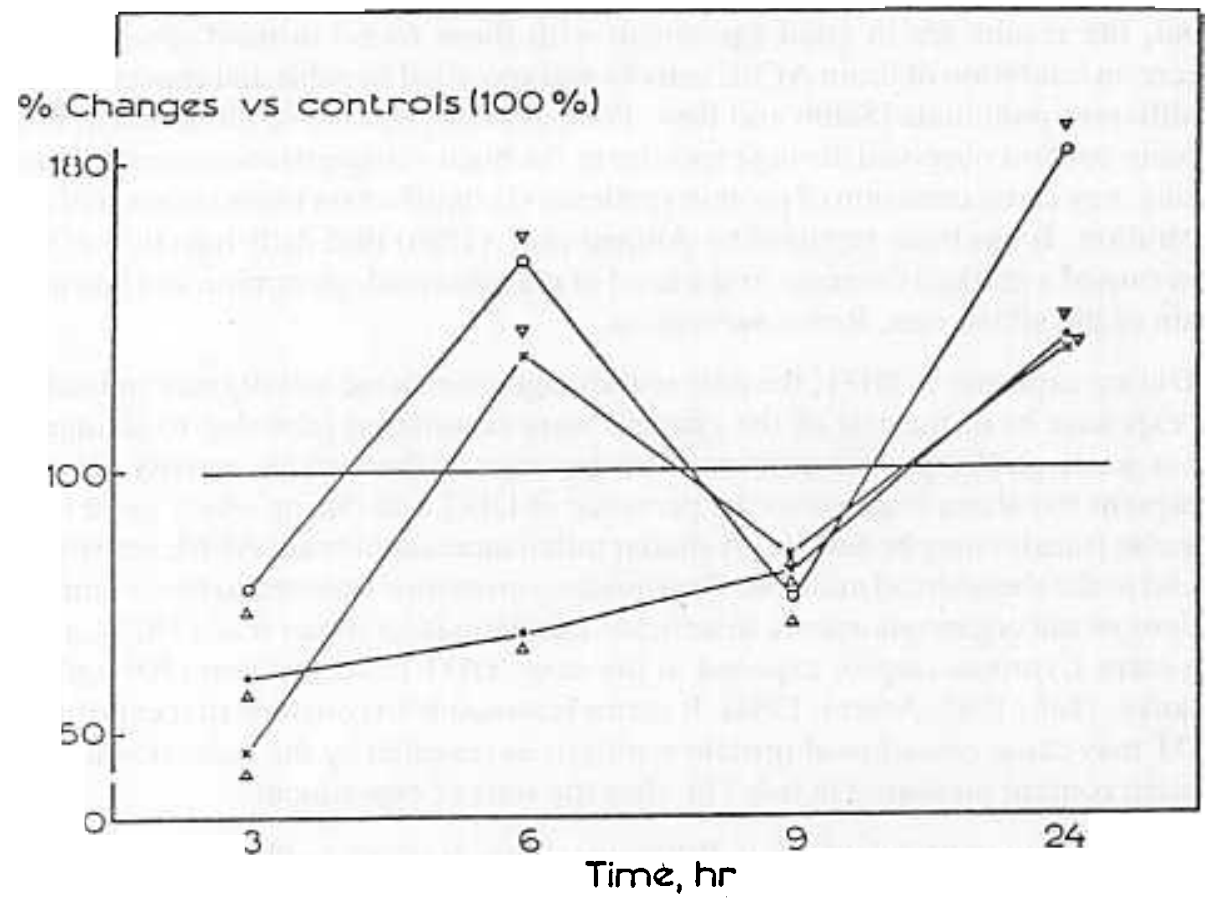

Fig. 8. Correlation of plasma AChE specific activity $\circ$ $\circ$, total activity $\times$ $x$ and protein concentration $\bullet \longrightarrow$ in percentage of controls during $24 \mathrm{hr}$ of exposure to $500 \mu \mathrm{g} / \mathrm{liter}$ DDT.

From these changes the inhibition or activation of the AChE may be due to the following causes: (1) Inhibition or activation possibly due to the effects of pollutants on the enzyme unit (specific activity), (2) Inhibition or activation due to changes in brain water content (total activity), and (3) Inhibition or activation due to changes in brain protein content ( $\mathrm{mg} / \mathrm{mg}$ fresh weight).

In the present work, the first cause was considered as the real changes and those changes due to the second or third cause were nominated as false changes. In the light of these assumption and during exposure to atrazine at its lower concentration $(100 \mu \mathrm{g} /$ liter $)$, a real inhibition of $(24 \%)$ of $\mathrm{AChE}$ specific activity by exposure $\mathrm{hr} 6$, was measured, during this period the $\mathrm{AChE}$ total activity was also reduced which indicate a state of brain dehydration as reconfirmed by the simultaneous significant increase in brain protein content $(14 \%)$. A similar real inhibition was also recorded by exposure hr 9 in brain of fish exposed to atrazine at its higher concentration $(500 \mu \mathrm{g} /$ liter).

These results may indicate that atrazine produced a dose-dependent brain AChE inhibition within the first $9 \mathrm{hr}$ of exposure. These results are in odd with those observed by Hanke et al. (1983) where the brain AChE activity of Cyprinus carpio had 


\section{References}

Ahmed, N.A., Rawi, S.M. and El-Behary, M.H. (1986) Effect of dieldrin injection on the level of certain amino acids and some enzymes in rat brain. Comp. Biochem. Physiol. 850: 437-442.

Aldridge, W.V. (1971) The nature of reaction of organophosphorus compound and carbamates with esterases. A Rep. Prog. Chem. (Chem. Soc. Lond.), 53: 294.

Assem, H. (1984) Potential use of physiological changes as indices of stress in the teleost; Cyprinus carpio. Bull. Inst. Oceanogr. Fish. A.R.E., 10: 111-121.

Assem, H., Abo Hegab, S. and Elsaeidy, I. (1993) In vivo changes in the activity of gill ATPases, muscle cell volume, and plasma and cellular ionic concentration of the African catfish, Clarias gariepinus induced by atrazine or DDT at different sublethal concentrations. J.K.A.U.: Mar. Sci., Vol. 6 (in press).

Aubin, A.E. and Johansen, P.H. (1969) The effects of an acute DDT exposure on the spontaneous electrical activity of gold fish cerebellum. Can.J. Zool., 47: 163-166.

Coppage, D.L. and Matthews, E. (1974) Short-term effects of organophosphate pesticides on cholinesterase of estuarine fishes and pink shrimp. Bull. Environ. Contam. Toxicol.: 11: 483-488.

Coppage, D.L., Matthews, E., Cook, G.H. and Knight, J. (1975) Inhibition in fish as a diagnosis of environment inhibiting by malathion. Pestic. Biochem. Pharmac., 6: 538-542.

Goodman, L.R., Hansen, D.H., Coppage, D.L., Moore, J.C. and Matthews, R.C. (1979) Diazinon: chronic toxicity to, and brain, acetylcholinesterase inhibition in the sheepshead minnow, Cyprinodon variegatus. Trans. Am. Fish. Soc. 108: 479-488.

Hanke, W., Gluth, G., Bubel, H. and Muller, R. (1983) Physiological changes in carps induced by pollution. Ecotox. Environm. Safety, 7: 229-241.

Hilmy, A.M., Badawi, H.K. and Shabana, M.B. (1983) Organochlorine pesticide residues in 12 freshwater Egyptian fish species with special emphasis on Anguilla vulgaris and Mugil cephalus. Comp. Biochem. Physiol. 760: 163-171.

Kaczmarek, L.K., Agarwal, H.C. and Division, A.N. (1970) Biochemical studies of taurine in the developing rat brain. Biochem. $J$, , 119: 45.

Lockridge, O., Mottershaw-Jackson, N., Echerson, H.W. and La Du, B.N. (1980) Hydrolysis of diacetylmorphine (hereoin) by human serum cholinesterases. J. Pharmac. Exp. Therm., 215: 1-8.

Matsumura, F. and Narahashi, T. (1971) ATPase inhibition and electrophysiological change caused by DDT and related neuroactive agents in lobster nerve. Biochem. Pharmac., 20: 825-837.

Myers, C., Lockridge, O. and La Du, B.N. (1982) Hydrolysis of methylprednisolone acetate by human serum cholinesterase. Drug. Met. Disp., 10: 279-280.

O'brien, R.D. (1960) Toxic Phosphorus Esters, Chemistry, Metabolism and Biological Effects. Academic Press, New York, U.S.A.

Sahib, I.R. and Rao, K.V.R. (1980) Correlation between subacute toxicity of malathion and acetylcholinesterase inhibition in the tissues of teleosts; Tilapia mossambica. Bull. Environ. Contam. Toxicol., 24: 711-718.

Skau, K.A. (1985) Acetylcholinesterase molecular forms in serum and erythrocytes of laboratory animals. Comp. Biochem. Physiol, 80c: 207-210. 